\title{
Effects of Dietary Incorporation of Grape Stalks Untreated and Fungi-Treated in Growing Rabbits: A Preliminary Study
}

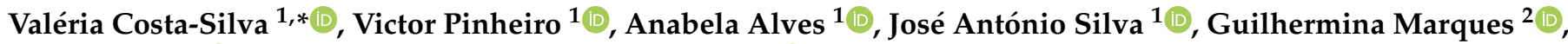 \\ Jose Lorenzo $^{3}{ }^{(1)}$, Miguel Rodrigues ${ }^{2}$ and Luís Ferreira ${ }^{2}(1)$
}

1 Animal and Veterinary Research Centre, Department of Animal Science, University of Trás-os-Montes and Alto Douro, 5000 Vila Real, Portugal; vpinheir@utad.pt (V.P.); anabela.gaalves@gmail.com (A.A.); jasilva@utad.pt (J.A.S.)

2 Centre for the Research and Technology of Agro-Environmental and Biological Sciences, University of Trás-os-Montes e Alto Douro, 5000 Vila Real, Portugal; gmarques@utad.pt (G.M.); mrodrigu@utad.pt (M.R.); lmf@utad.pt (L.F.)

3 Centro Tecnolóxico da Carne de Galicia, rúa Galicia n 4, Parque Tecnolóxico de Galicia, San Cibrao das Viñas, 32900 Ourense, Spain; jmlorenzo@ceteca.net

* Correspondence: valeriasilva@utad.pt

Citation: Costa-Silva, V.; Pinheiro, V.; Alves, A.; Silva, J.A.; Marques, G.;

Lorenzo, J.; Rodrigues, M.; Ferreira, L. Effects of Dietary Incorporation of Grape Stalks Untreated and Fungi-Treated in Growing Rabbits: A Preliminary Study. Animals 2022, 12, 112. https://doi.org/10.3390/ ani12010112

Academic Editors: Yimin Cai, Zaenal Bachruddin, Jianguo Zhang and Cesare Castellini

Received: 3 December 2021

Accepted: 2 January 2022

Published: 4 January 2022

Publisher's Note: MDPI stays neutral with regard to jurisdictional claims in published maps and institutional affiliations.

Copyright: (C) 2022 by the authors. Licensee MDPI, Basel, Switzerland. This article is an open access article distributed under the terms and conditions of the Creative Commons Attribution (CC BY) license (https:// creativecommons.org/licenses/by/ $4.0 /)$.
Simple Summary: The use of winery by-products as an animal feed ingredient in rabbit production can enhance the sustainability of this livestock sector by reducing feeding costs and simultaneously diminishing environmental problems related to the management of those by-products. White-rot fungi have been studied for the delignification of lignocellulosic materials due to their potential to decrease the content of lignin. In fact, white-rot fungi also improve the nutritional value due to the deposition of bioactive compounds, acting as a possible biological treatment to enhance the nutritive value of grape stalks. The objective of this work was to evaluate the incorporation of untreated grape stalks and fungi-treated grape stalks in rabbits' diets.

Abstract: This study aimed to evaluate the effect of the incorporation of untreated grape stalks $\left(\mathrm{U}_{\mathrm{GS}}\right)$ and fungi-treated grape stalks (Lentinula edodes, $\mathrm{T}_{\mathrm{GS}}$ ) in rabbits' diets. The control group was fed with a control diet without grape stalks (C), two experimental groups were fed on diets with 5\% and $10 \%$ incorporation of $\mathrm{U}_{\mathrm{GS}}\left(5 \mathrm{U}_{\mathrm{GS}}\right.$ and $\left.10 \mathrm{U}_{\mathrm{GS}}\right)$, and two with $5 \%$ and $10 \%$ incorporation of $\mathrm{T}_{\mathrm{GS}}\left(5 \mathrm{~T}_{\mathrm{GS}}\right.$ and $\left.10 \mathrm{~T}_{\mathrm{GS}}\right)$. Rabbits fed with $\mathrm{T}_{\mathrm{GS}}$ diets showed higher daily weight gain $(p=0.034)$, feed conversion rate $(p=0.002)$, carcass weight $(p=0.038)$, and reference carcass weight $(p=0.03)$ when compared to the control diet. Moreover, animals fed with $\mathrm{T}_{\mathrm{GS}}$ diets showed an increase in the caecum $(p=0.015)$ and small intestine $(p=0.021)$ lengths and in the total volatile fatty acid content $(p=0.005)$ compared to animals fed $\mathrm{U}_{\mathrm{GS}}$ diets. Blood triglyceride levels were lower in animals fed with $\mathrm{T}_{\mathrm{GS}}$ diets compared to $\mathrm{U}_{\mathrm{GS}}(p=0.005)$ and $\mathrm{C}(p \leq 0.001)$ diets $(12 \%$ and $19 \%$ lower, respectively), and a trend to lower cholesterol levels was observed $(p=0.071)$. Meat from rabbits fed with $\mathrm{T}_{\mathrm{GS}}$ diets had higher levels of linoleic acid, $\gamma$-linolenic, $\sum \omega-6, \sum$ PUFA, and $\sum$ PUFA/ $\sum$ SFA ratio compared to rabbits fed with the $C$ diet. Results indicated that grape stalks $\left(\mathrm{U}_{\mathrm{GS}}\right.$ and $\mathrm{T}_{\mathrm{GS}}$ ) could be effectively used as an alternative raw material in rabbits' diets without compromising animal performance.

Keywords: agricultural by-product; grape stalks; growing rabbits; nutritional value; meat quality white-rot fungi

\section{Introduction}

The utilization of winery wastes in animal feeding may represent a viable strategy for livestock production as it could reduce feed costs and make a vital contribution to the possible shortage of raw materials, thus presenting a solution for the environmental problems created by agricultural industries [1,2]. The International Organisation of Vine and Wine (OIV) estimated a global wine production of $294 \mathrm{mhL}$ in 2018 and $60 \%$ of that 
production is carried out by European Union countries. The generated by-products have been estimated to be around $25-30 \mathrm{~kg} / \mathrm{hL}$ of produced wine, and on average, $4 \mathrm{~kg}$ of grape stalks are generated per each $\mathrm{hL}$ of produced wine, representing $10-15 \%$ of the total produced wastes [3,4]. Currently, grape stalks have been used as fertilizers, but most of the time they are disposed to landfills which, when not attended correctly, can cause environmental problems [5,6]. The nutritional content of grape stalks may not be appealing, limiting its use as a raw material for animal feeding, as they constitute a lignocellulosic fiber material composed mainly of cellulose (30-38\%), hemicelluloses (14-21\%), and lignin (17-33\%) [4,7-9]. The high lignin content can be responsible for the limited cell wall digestibility, caused by the strong linkages between lignin and polysaccharides that challenge the enzymatic hydrolysis of cell walls, with consequent negative effects on animal performance [10]. In recent years, there has been an increased interest in the use of biological treatments for lignocellulosic biomass, such as solid-state fermentation with fungi as an alternative for chemical and physical treatments. White-rot fungi are the most efficient microorganisms performing delignification, due to an enzymatic system with extracellular oxidative enzymes (such as laccase, lignin peroxidases, manganese-dependent peroxidase, versatile peroxidase, and others) that catalyze the initial steps of lignin oxidation and depolymerization $[9,11]$. The modification of lignin structure (delignification) will increase the access to cellulose and hemicellulose and enhance the digestibility of the lignocellulosic biomass. Many studies have evaluated the effect of biological treatment on lignocellulosic biomass with fungi, mainly in sheep [12-16], cattle [17-20], and rabbits [21-23]. In this context, the objective of this study was to evaluate the dietary incorporation of untreated and fungi-treated grape stalks with Lentinula edodes on the diets of growing rabbits.

\section{Materials and Methods}

The experimental trial was conducted according to the Portuguese legislation (Ports. no. 1005/92, 214/08, 635/09) on animal welfare. The ethical committee of the University of Trás-os-Montes and Alto Douro (ORBEA, Animal Welfare Authority) approved the experimental protocol (Process number: 1058-e-DZ-2019).

\subsection{Untreated and Treated Grape Stalks}

Grape stalks (GS) were collected after the destalking process in the region of Trásos-Montes, Murça, district of Vila Real, Portugal. Grape stalks were dried at $40^{\circ} \mathrm{C}$ in an air forced oven (Venticell, MMM Group, Munich, Germany), then ground by a hammer mill (Retsch SM 100, Haan, Germany) at $1 \mathrm{~cm}$ and stored for subsequent processing. The stored material was divided into two parts, one designated untreated grape stalks $\left(\mathrm{U}_{\mathrm{GS}}\right)$ and stored until the rabbit feed production, and the other one treated $\left(\mathrm{T}_{\mathrm{GS}}\right)$ with the basidiomycete Lentinula edodes from the culture collection of the Laboratory of Mycology and Soil Microbiology of the University of Trás-os-Montes and Alto Douro, Vila Real, Portugal. Lentinula edodes was selected based on the results obtained in a preliminary study (unpublished data) that showed that this fungal strain had a greater potential for the improvement of the nutritional value of grape stalks for rabbit feeding. For the solid-state fermentation (SSF) process, approximately $1 \mathrm{~kg}$ of humidified grape stalks was placed in several breathable autoclaving bags (filter type $\mathrm{T}$; filter pore size of $0.2 \mu \mathrm{m}$; Unicornbags, Plano, TX, USA), autoclaved ( $121^{\circ} \mathrm{C}$ for $30 \mathrm{~min}$ ) in an autoclave machine (MLS-3781L-PE, Panasonic Healthcare, Gunma, Japan), cooled, and inoculated with $40 \mathrm{~g}$ of grain spawn of L. edodes at $28^{\circ} \mathrm{C}$ for 50 days.

\subsection{Experimental Diets}

Diets were formulated according to the recommendations of De Blas and Mateos [24] for growing rabbits. Two diets with 100 and $50 \mathrm{~g} / \mathrm{kg}$ of incorporation of untreated grape stalks ( $10 \mathrm{U}_{\mathrm{GS}}$ and $5 \mathrm{U}_{\mathrm{GS}}$, respectively), two diets with 100 or $50 \mathrm{~g} / \mathrm{kg}$ of incorporation of fungi-treated grape stalks ( $10 \mathrm{~T}_{\mathrm{GS}}$ and $5 \mathrm{~T}_{\mathrm{GS}}$, respectively), and a control diet without 
incorporation of grape stalks were used. The feed ingredients $(\mathrm{g} / \mathrm{kg}$, as fed) and their chemical composition are shown in Table 1.

Table 1. Ingredients ( $\mathrm{g} / \mathrm{kg}$, as fed) and chemical composition ( $\mathrm{g} / \mathrm{Kg}$, as fed) of the five experimental diets.

\begin{tabular}{|c|c|c|c|c|c|}
\hline & \multicolumn{5}{|c|}{ Experimental Diets } \\
\hline & $\mathrm{C}$ & $5 \mathrm{U}_{\mathrm{GS}}$ & $10 U_{G S}$ & $5 \mathrm{~T}_{\mathrm{GS}}$ & $10 \mathrm{~T}_{\mathrm{GS}}$ \\
\hline \multicolumn{6}{|l|}{ Ingredients ( $\mathrm{g} / \mathrm{kg}$, as fed) } \\
\hline Grape Stalk untreated & 0 & 50 & 100 & 0 & 0 \\
\hline Grape Stalk treated & 0 & 0 & 0 & 50 & 100 \\
\hline Alfalfa hay & 180 & 180 & 180 & 180 & 180 \\
\hline Sunflower meal & 200 & 185 & 115 & 180 & 125 \\
\hline Wheat & 100 & 110 & 100 & 100 & 110 \\
\hline Beet pulp & 80 & 80 & 100 & 100 & 80 \\
\hline Rice bran & 50 & 50 & 10 & 50 & 10 \\
\hline Wheat bran & 150 & 150 & 150 & 150 & 150 \\
\hline Wheat straw & 70 & 15 & 15 & 15 & 10 \\
\hline Corn bran & 20 & 20 & 25 & 40 & 25 \\
\hline Corn gluten feed & 0 & 25 & 50 & 0 & 55 \\
\hline Palm kernel & 60 & 60 & 55 & 60 & 55 \\
\hline Soy husk & 30 & 15 & 0 & 15 & 0 \\
\hline Soybean & 0 & 0 & 40 & 0 & 40 \\
\hline Sugarcane molasses & 20 & 20 & 20 & 20 & 20 \\
\hline Minerals, vitamins and additives ${ }^{1}$ & 40 & 40 & 40 & 40 & 40 \\
\hline \multicolumn{6}{|l|}{ Chemical composition (g/kg DM) } \\
\hline Organic matter & 899 & 908 & 908 & 909 & 900 \\
\hline Ash & 101 & 92 & 92 & 91 & 100 \\
\hline NDFom & 406 & 389 & 385 & 389 & 379 \\
\hline Total dietary fiber & 455 & 462 & 465 & 474 & 472 \\
\hline Insoluble fiber & 405 & 418 & 421 & 423 & 413 \\
\hline Soluble fiber & 50 & 44 & 44 & 51 & 59 \\
\hline Crude protein & 138 & 134 & 142 & 132 & 138 \\
\hline Ether extract & 41 & 40 & 41 & 44 & 43 \\
\hline Gross energy (kcal/kg, as fed) & 2252 & 2253 & 2253 & 2252 & 2252 \\
\hline
\end{tabular}

C: control diet without grape stalks incorporation; $10 \mathrm{U}_{\mathrm{GS}}, 5 \mathrm{U}_{\mathrm{GS}}$ : diets with the incorporation of $100 \mathrm{and} 50 \mathrm{~g} / \mathrm{kg}$ of untreated grape stalks, respectively; $10 \mathrm{~T}_{\mathrm{GS}}, 5 \mathrm{~T}_{\mathrm{GS}}$ : diets with the incorporation of 100 and $50 \mathrm{~g} / \mathrm{kg}$ of treated grape stalks with L. edodes, respectively; SEM: standard error of the mean; NDFom: neutral detergent fiber ash-free; 1: vitamin A, 10,000 IU; vitamin D3, $1080 \mathrm{U}$; vitamin E, $36 \mathrm{mg}$; vitamin K, $1 \mathrm{mg}$; vitamin B1, $2 \mathrm{mg}$; vitamin B2, $6 \mathrm{mg}$; vitamin B6, $2 \mathrm{mg}$; vitamin B12, $10 \mathrm{mg}$; niacinamide, $50 \mathrm{mg}$; Ca- pantothenate, $20 \mathrm{mg}$; folic acid, $5 \mathrm{mg}$; $\mathrm{Fe}$, $78 \mathrm{mg}$; Cu, $14 \mathrm{mg}$; Co, $0.5 \mathrm{mg}$; Mn, $20 \mathrm{mg}$; Zn, $60 \mathrm{mg}$; Se, $0.05 \mathrm{mg}$; I, $1.1 \mathrm{mg}$; choline chloride, $260 \mathrm{mg}$. In addition, Calcium carbonate, Luctarom 1408-Z, L-Threonine, Toxmystat, Luctanox, Sepiolite, NL-510-R, salt, Biolys 70, Sodium bicarbonate and Bio-Mos.

\subsection{Animals and Experimental Design}

Fifty hybrid (New Zealand $\times$ Californian) male rabbits weaned at 35 days of age with an average body weight of $1091 \pm 56.3 \mathrm{~g}$ were randomly assigned to five experimental treatment groups (10 rabbits/diet). Animals were kept in a closed air-conditioned building maintained between 18 and $23{ }^{\circ} \mathrm{C}$ and received $12 \mathrm{~h}$ of light daily. The experimental diets were restricted to $90 \mathrm{~g} /$ day on the first week and $100 \mathrm{~g} /$ day on the second week to avoid digestive problems, as GS were never used on rabbits feeding, and animals were then provided ad libitum until the end of the experiment. No animals died during the experimental period.

\subsection{Growth Performance Trial}

During the experimental period (from $35 \mathrm{~d}$ until $66 \mathrm{~d}$ ), individual live weight and feed intake per cage were measured and the weight gain, daily feed intake, and feed conversion ratio were calculated. No animals died during the trial. Feed consumption was calculated as grams per rabbit per day. Refusals from each cage were collected daily, weighed, and taken into consideration for the calculation of feed consumption and feed conversion ratio (g feed/g gain). 


\subsection{Digestibility Trial}

The coefficients of total tract apparent digestibility (CTTAD) of dry matter (DM), organic matter $(\mathrm{OM})$, neutral detergent fiber ash-free (NDFom), crude protein $(\mathrm{CP})$, and ether extract (EE) were measured in six randomly selected rabbits from each experimental diet were determined from 55 to $59 \mathrm{~d}$ of age during the growing trial according to the European standardized method [25]. Feces were collected using nylon net placed under each individual cage to avoid urine contamination. Samples of feeds and feces were collected individually and then stored at $-20^{\circ} \mathrm{C}$ for subsequent chemical analysis. Feed consumed was registered weekly and total fecal excretion was quantified daily from each cage for further calculations.

\subsection{Chemical Analysis}

All samples (feed and feces) were dried at $60^{\circ} \mathrm{C}$ to a constant weight in an air forced oven (Venticell, MMM Group, Munich, Germany). The samples were grounded over a $1 \mathrm{~mm}$ screen (Tecator Cyclotec 1093 Sample Mill, Foss SA, Sweden) and prepared for chemical analysis. AOAC [26] procedures were used to determine DM (no. 934.01), OM and ash (no. 942.05), ether extract (EE, no.920.39), total dietary fiber, soluble and insoluble fiber (no. 991.43), and total $\mathrm{N}$ as per the Kjeldahl method (954.01). The CP content was calculated as $\mathrm{N}$ crude protein (CP, no. 954.01). The NDFom was determined without the use of sodium sulfite and $\alpha$-amylase according to the methodologies proposed by Robertson and Van Soest [27] and Van Soest et al. [28].

\subsection{Slaughtering, Sampling, and Post-Slaughter Analysis}

At 66 days of age, the animals were slaughtered by cervical dislocation. The slaughtering and carcass dissection procedures followed the World Rabbit Science Association recommendations described by Blasco and Ouhayoun [29].

\subsubsection{Blood Analysis}

Blood samples were collected during slaughtering directly from the jugular vein into tubes containing ethylenediaminetetraacetic acid tripotassium (K3EDTA; Sigma Company, St. Louis, MO, USA). Hematologic parameters were measured using a hematology analyzer and the respective reagent kit supplied by the manufacturer (Procyte Dx, IDEXX Laboratories, Westbrook, ME, USA). The hematology analyzer combines three major technologies: laser flow cytometry, optical fluorescence, and laminar flow impedance. The hematologic parameters evaluated were erythrocyte, haemoglobin, haematocrit, lymphocytes, monocytes, eosinophils, basophils, and reticulocyte count. For serum biochemistry, samples were let to coagulate and centrifuged at $3500 \mathrm{rpm}$ for $15 \mathrm{~min}$ and serum was separated and stored at $-20{ }^{\circ} \mathrm{C}$ till analyzed. Serum biochemical parameters were measured using automated biochemistry analyser using reagents, calibrators and controls supplied by the manufacturer (Daytona, Randox Laboratories Ltd., CrumLin, UK). The following serum biochemical parameters were estimated: triglycerides, cholesterol, urea, creatinine, aspartate aminotransferase, alanine, albumin, and total protein.

\subsubsection{Caecal and Gastrointestinal Parameters}

Immediately after slaughter, $\mathrm{pH}$ of caecal and stomach content, full and empty gastrointestinal tract weight and length, scapular, pelvic and perivisceral fat, liver and kidneys weights were registered. Samples from the small intestine (duodenum, jejunum, and ileum), liver, and kidney were collected and fixed by immersion in 10\% neutral formalin for further analysis (villus and viscera observation). For volatile fatty acids (VFA) analysis, samples of caecal content were collected and frozen. Samples of caecal contents were centrifuged at $10,000 \mathrm{rpm}$ for $15 \mathrm{~min}$ at $4{ }^{\circ} \mathrm{C}$ and $5 \mathrm{~mL}$ of supernatant were collected and was added $0.5 \mathrm{~mL}$ of pivalic acid. Then, $4 \mathrm{~mL}$ of this solution was mixed with $1 \mathrm{~mL}$ of $\mathrm{H}_{3} \mathrm{PO}_{4} 25 \%$ and were centrifuged at 10,000 rpm for $10 \mathrm{~min}$ at $4{ }^{\circ} \mathrm{C}$. The supernatant was collected for volatile fatty acid (VFA) analysis. VFA concentrations were determined by gas-liquid chromatography 
(Shimadzu GC-141 B, Kyoto, Japan) using pivalic acid as an internal standard according to the procedures of Czerkawski [30]. Separation of acetate, propionate, butyrate, and valeric was accomplished on a capillary column (Supelco Nukol, $30 \mathrm{~m} \times 0.25 \mathrm{~mm}$, df $0.25 \mu \mathrm{m}$ ), operated at $135^{\circ} \mathrm{C}$ using helium as the carrier gas. The injection temperature was $210^{\circ} \mathrm{C}$. Quantification of the acids was performed using a flame ionization detector at $180{ }^{\circ} \mathrm{C}$ connected to an integrator (Shimadzu C-R6A, Kyoto, Japan).

\subsubsection{Villus and Viscera Observation}

Samples collected and fixed by immersion in $10 \%$ neutral formalin during slaughtering were processed in an automatic tissue processor (Hipercenter XP, Shandon, Cornelius, NC, USA). Samples were dehydrated in increasing ethanol concentrations, cleared in xylene, embedded in paraffin wax (Histoplast, Shandon, Cornelius, NC, USA), and sectioned to a thickness of $3 \mu \mathrm{m}$. The sections were routinely stained with hematoxylin and eosin [31]. Slides were evaluated on a stationary digital camera (DXM1200, Nikon, Tokyo, Japan) using optical lens no 4 to measure the height, tip width, crypt depth, and muscle layer thickness. Fifteen villi per animal were assessed and the reported mean values were based on these measurements. A digital program (Digimizer, MedCalc Software Ltd., Ostend, Belgium) was used to measure the characteristics of crypts.

\subsubsection{Carcass Parameters}

Hot carcass weight $(\mathrm{HCW})$ did not include blood, skin, distal parts of the tail, fore and hind legs, gastrointestinal and urogenital tracts. After being chilled at $4{ }^{\circ} \mathrm{C}$ for $24 \mathrm{~h}$, carcass weight (CCW) was recorded, and $\mathrm{pH}(\mathrm{pH} 24)$ and color carcass were assessed in the left biceps femoris muscle (BFM). The $\mathrm{pH}$ was measured directly in the muscle with a 5-mm glass penetration $\mathrm{pH}$ electrode ( $\mathrm{pH}$ Meter 632, Metrohm, Herisau, Switzerland) and the carcass colors were measured in accordance with Ouhayoun and Dalle Zotte [32] using a color measurement instrument (CR-300 Chroma Meter, Minolta, Osaka, Japan) in the CIELAB color space: lightness $\left(\mathrm{L}^{*}\right)$, redness $\left(\mathrm{a}^{*}\right)$, and yellowness $\left(\mathrm{b}^{*}\right)$. The weight of the hindleg, each thigh, loin, rib, paw, head, liver, kidneys, organs of thorax and neck (LHW- thymus, trachea, esophagus, lungs, and heart), and perirenal fat were recorded for each carcass and their ratio to the CCW and reference carcass weight (RCW) calculated. Longissimus muscle was excised by removing the skin and connective tissue and stored at $4{ }^{\circ} \mathrm{C}$ until $48 \mathrm{~h}$ post-mortem for meat quality analysis, e.g., $\mathrm{pH}$, color, cooking losses, and shear force.

\subsubsection{Meat Quality}

The left longissimus muscle was used to measure $\mathrm{pH}$, color, cooking losses, and shear force. Meat $\mathrm{pH}(\mathrm{pH} 48)$ and color were measured as previously referred. The cooking losses (\%) were determined by individually placing meat samples inside polyethylene bags in a water bath at $80^{\circ} \mathrm{C}$ for $1 \mathrm{~h}$ and cooled for 15 min under running tap water. The samples were then dried with filter paper and weighed. The cooking losses were expressed as the percentage of weight loss relative to the initial weight. After measuring the cooking losses, the samples were stored overnight in a refrigerator $\left(4^{\circ} \mathrm{C}\right)$. The meat samples used to determine the cooking loss were then cut into cuboid shape sub-samples (4) of $1 \mathrm{~cm}^{2}$ cross-section and 3-4 cm in length to determine the shear force, after room temperature equilibrium, using a Warner-Bratzler rectangular hole probe coupled to a TA.XT plus texturometer with a load cell of $30 \mathrm{~kg} / \mathrm{f}$ (Stable Micro Systems, Godalming, UK). To perform these analyses, trigger force and blade velocity were set to $120 \mathrm{~cm} / \mathrm{min}$ and $5 \mathrm{~g}$ respectively, and the sub-samples were placed with fibers perpendicular to the direction of the blade. Mean values for maximum shear force $\left(\mathrm{N} / \mathrm{cm}^{2}\right)$ over each sub-sample group were then obtained. 


\subsubsection{Fatty-Acid Profile}

The right longissimus muscle of each animal was used to analyze the major fatty acids. The fatty acids were obtained using the protocol described by Bligh and Dyer [33] with modifications proposed by Barros [34]. Once the fatty acids were extracted, these compounds were transesterified according to the method described by Domínguez et al. [35], with some modifications. For sample preparation the method described by Munekata et al. [36] was used. The fatty acid methyl esters (FAMEs) were separated and quantified by gas chromatography (GC-Agilent 7890B, Agilent Technologies, Santa Clara, CA, USA) equipped with a PAL RTC-120 autosampler and a flame ionization detector (FID). The injection was carried out in split mode (1:50) with $1 \mathrm{~L}$, the injector was kept at $260{ }^{\circ} \mathrm{C}$, and the total flow was set to $64.2 \mathrm{~mL} / \mathrm{min}$. The separation was carried in an SP-2560 fused silica capillary column (100 m, $0.25 \mathrm{~mm}$ inner diameter (i.d.), 0.25-m film thickness; Supelco Inc., Bellefonte, PA, USA). The software MassHunter GC/MS Acquisition B.07.05.2479 (Agilent Technologies, Santa Clara, CA, USA) was used to control the equipment and perform the data analysis. Authenticated standards (FAME Mix, 37 components, docosapentaenoic acid, trans-vaccenic acid, cis-vaccenic acid, and CLA) were used to identify the FAMEs by comparing the retention times. The results were expressed as $\mathrm{g} / 100 \mathrm{~g}$ of total identified fatty acids. After obtaining the fatty-acid data, the fractions of saturated ( $\sum$ SFA), monounsaturated ( $\sum$ MUFA), polyunsaturated ( $\sum$ PUFA), and omega 3 and 6 ( $\sum \omega-3$ and $\left.\sum \omega-6\right)$ fatty-acid contents were determined, and the ratio $\sum$ PUFA/ $\sum$ SFA was calculated.

\subsection{Statistical Analysis}

Statistical analysis was carried out using the JMP program version 14 (SAS, 2018). Diet effect $\left(\mathrm{C} ; 5 \mathrm{U}_{\mathrm{GS}} ; 10 \mathrm{U}_{\mathrm{GS}} ; 5 \mathrm{~T}_{\mathrm{GS}}\right.$ and $\left.10 \mathrm{~T}_{\mathrm{GS}}\right)$ on the analyzed parameters was determined by analysis of variance (ANOVA). Orthogonal contrasts were performed to evaluate the effect of the incorporation of untreated or treated grape stalks vs. control diet, and the effect of the incorporation of untreated grape stalks vs. treated grape stalks (C vs. $5 \mathrm{U}_{\mathrm{GS}}+10 \mathrm{U}_{\mathrm{GS}}, \mathrm{C}$ vs. $5 \mathrm{~T}_{\mathrm{GS}}+10 \mathrm{~T}_{\mathrm{GS}}$, and $\mathrm{U}_{\mathrm{GS}}$ vs. $\left.\mathrm{T}_{\mathrm{GS}}\right)$. Differences were considered statistically significant at $p<0.05$.

\section{Results and Discussion}

Experimental diets were similar in their chemical composition (Table 1) for CP $(136.8 \pm 3.2 \mathrm{~g} / \mathrm{kg}$, as fed), CF (41.8 $\pm 1.5 \mathrm{~g} / \mathrm{kg}$, as fed), gross energy (2252.4 $\pm 0.4 \mathrm{kcal} / \mathrm{kg})$, and NDFom content $(389.6 \pm 8.8 \mathrm{~g} / \mathrm{kg}$, as fed). The inclusion of several ingredients (i.e., corn gluten feed, soybean, sunflower meal, rice bran, wheat straw, and soy husk) was not equivalent on all diets due to the different chemical composition of both untreated $\left(\mathrm{U}_{\mathrm{GS}}\right)$ and treated grape stalks $\left(\mathrm{T}_{\mathrm{GS}}\right)$.

Overall, the experimental diets did not result in significant changes in animal performance, except daily weight gain (DWG), carcass weight (CW) and reference $\mathrm{CW}$, lengths of the gastrointestinal tract, volatile fatty acids (VFA) profile, triglycerides and urea levels, and fatty acids profile. Data on growth performance and carcass traits are presented in Table 2. Higher daily weight gain (DWG) was observed on $\mathrm{T}_{\mathrm{GS}}$ diets compared to the control diet $(p=0.034)$ and a trend $(p=0.069)$ for higher DWG was also observed compared to $\mathrm{U}_{\mathrm{GS}}$. Rabbits fed on $\mathrm{T}_{\mathrm{GS}}$ diets showed a lower feed conversion rate compared to rabbits fed on $\mathrm{C}$ and $\mathrm{U}_{\mathrm{GS}}$ diets ( $p=0.002$ and $p=0.056$, respectively). Carcass weight (CW) and reference $\mathrm{CW}$ were higher for the $\mathrm{T}_{\mathrm{GS}}$ diets compared to the control diet $(p=0.038$ and $p=0.030$; respectively). Similar performance results were reported by several authors [37-39] in rabbits fed on diets containing fungi-treated substrates when compared to rabbits fed on diets including the non-treated substrates. El-Kady et al. [38] evaluated the replacement of hay for untreated corn stalks and those treated with Trichoderma reesei on rabbit's diets and reported an increase of the DWG in an average of $28 \%$ for the treated cornstalks diet when compared to the control diet and $18 \%$ for diets containing untreated corn stalks. A similar trend was reported by Omer et al. [39] when studying the effect of the incorporation of rice straw treated with $P$. ostreatus and corn stalks with $T$. reesei, with rabbit's fed on diets 
containing treated materials showing an increase in DWG of $11 \%$ compared to the control diet. According to Omer et al. [39], these positive effects on DWG could be attributed to secondary metabolites (such as exogenous enzymes, amino acids, or even vitamins) as a result of fungi mycelium growth on a substrate, and these can also influence the functionality of the gastrointestinal tract and feed efficiency [39]. The lower feed conversion ratio observed for $\mathrm{T}_{\mathrm{GS}}$ diets also corroborates these findings (Table 2). However, data on CTTAD (Table 3) and the intestinal morphology of growing rabbits show that there were no differences between diets, indicating that other factors may have influenced the enhanced DWG and feed conversion rate. The morphology of villi and crypts are associated with gastrointestinal function, influencing the intestinal health status and its absorptive capacity. So, the gastrointestinal function and growth performance of rabbits are directly associated $[40,41]$. Results presented in Table 4 show that the length of caecum on rabbits fed with TGS diets is $5.4 \%$ longer compared to UGS diets $(p=0.015)$ and a trend $(+4.7 \%)$ exists when compared to the control diet $(p=0.072)$. The same effect was observed for the small intestine measurements, with rabbits fed with TGS diets showing an increase of 5.6\% ( $p=0.021)$ compared to UGS diets (Table 4$)$. Digestion and nutrient absorption mostly occur in the small intestine, which accounts for a large part of the total digestibility of dietary amino acid and starch, while the cecum is responsible for approximately half of the total digestive tract capacity [42]. The level and type of dietary fiber can play the most important role in controlling gastrointestinal tract development and digestive content and regulates feed intake and retention time in the caecum [43]. The caecal VFA concentration (Table 4) on rabbits fed with TGS diets showed a decrease in total VFA $(-12.5 \% ; p=0.020)$, a decrease of acetic acid $(-2.6 \% ; p=0.005)$, and an increase of butyric acid $(-2.1 \% ; p=0.016)$ when compared with the incorporation of UGS, suggesting a different digestive efficiency between the experimental diets. VFA concentration is used as an indicator of microbial activity and significant dietary changes are required to modify VFAs due to their high variability [2]. For instance, the proportion of acetate increases, and that of butyrate generally decreases significantly when the fiber level increases [24]. Ribeiro et al. [21] showed the same trend of results for VFA profile when incorporating fungi-treated olive leaves in rabbit's diets, suggesting that this increase could be the result of changes in the fiber chemical composition from fungi treatment. In this way, it seems that data obtained for DWG, feed conversion ratio, carcass weight $(\mathrm{CW})$, and reference $C W$ could be the result of the different digestive efficiency as well as the increase in the total available area for nutrient absorption. Data presented in Table 5 show that the experimental diets did not influence the major hematology and serum biochemistry parameters in rabbits' blood.

Table 2. Effect of the experimental diets on growth performance and carcass traits $(n=10)$.

\begin{tabular}{|c|c|c|c|c|c|c|c|c|c|}
\hline & \multicolumn{5}{|c|}{ Experimental Diets } & \multicolumn{4}{|c|}{$p$-Value } \\
\hline & $\mathrm{C}$ & $5 \mathrm{U}_{\mathrm{GS}}$ & $10 U_{G S}$ & $5 \mathrm{~T}_{\mathrm{GS}}$ & $10 \mathrm{~T}_{\mathrm{GS}}$ & SEM & $\begin{array}{c}\text { C vs. } 5 U_{G S}+ \\
10 U_{G S}\end{array}$ & $\begin{array}{c}\text { C vs. } 5 T_{\mathrm{GS}}+ \\
10 \mathrm{~T}_{\mathrm{GS}}\end{array}$ & $\mathrm{U}_{\mathrm{GS}}$ vs. $\mathrm{T}_{\mathrm{GS}}$ \\
\hline Live weight at $35 \mathrm{~d}(\mathrm{~g})$ & 1094.4 & 1097.5 & 1094.9 & 1092.5 & 1077.0 & 18.4 & 0.936 & 0.671 & 0.538 \\
\hline Live weight at 66 d (g) & 2554.7 & 2590.2 & 2578.5 & 2662.2 & 2612.0 & 40.3 & 0.551 & 0.102 & 0.197 \\
\hline Daily weight gain $(\mathrm{g} / \mathrm{d})$ & 47.1 & 48.1 & 47.9 & 50.6 & 49.5 & 1.1 & 0.513 & 0.034 & 0.069 \\
\hline Daily feed intake (g/d) & 152.0 & 148.8 & 150.3 & 151.0 & 149.5 & 3.0 & 0.506 & 0.642 & 0.805 \\
\hline Feed conversion rate & 3.24 & 3.10 & 3.14 & 2.98 & 3.02 & 0.06 & 0.112 & 0.002 & 0.056 \\
\hline Carcass Weight $(\mathrm{CCW}),(\mathrm{g})$ & 1394.8 & 1440.4 & 1426.9 & 1474.4 & 1424.4 & 20.9 & 0.136 & 0.038 & 0.455 \\
\hline Reference CCW (RCW; g) & 1128.9 & 1176.6 & 1166.9 & 1203.5 & 1157.5 & 18.7 & 0.100 & 0.030 & 0.645 \\
\hline Carcass yield (\%HCW) & 54.7 & 55.6 & 55.4 & 55.4 & 54.6 & 0.54 & 0.204 & 0.617 & 0.342 \\
\hline RCW yield (\%CCW) & 80.9 & 81.7 & 81.8 & 81.6 & 81.2 & 0.38 & 0.100 & 0.304 & 0.439 \\
\hline \multicolumn{10}{|l|}{ Carcass color } \\
\hline $\mathrm{L}^{*}$ & 44.4 & 44.5 & 43.9 & 41.8 & 44.3 & 1.17 & 0.903 & 0.370 & 0.342 \\
\hline$a^{*}$ & 10.5 & 11.9 & 11.6 & 13.1 & 11.8 & 1.50 & 0.507 & 0.291 & 0.625 \\
\hline$b^{*}$ & 12.7 & 14.6 & 13.3 & 13.7 & 13.2 & 0.76 & 0.191 & 0.426 & 0.524 \\
\hline $\mathrm{pH}_{24}$ & 5.85 & 5.86 & 5.84 & 5.96 & 5.83 & 0.06 & 0.994 & 0.550 & 0.459 \\
\hline Drip loss (\%) & 4.36 & 3.80 & 3.71 & 3.68 & 3.81 & 0.23 & 0.074 & 0.070 & 0.973 \\
\hline As $\%$ of $C C W:$ & & & & & & & & & \\
\hline
\end{tabular}


Table 2. Cont.

\begin{tabular}{|c|c|c|c|c|c|c|c|c|c|}
\hline & \multicolumn{5}{|c|}{ Experimental Diets } & \multicolumn{4}{|c|}{$p$-Value } \\
\hline & C & $5 \mathrm{U}_{\mathrm{GS}}$ & $10 U_{\mathrm{GS}}$ & $5 \mathrm{~T}_{\mathrm{GS}}$ & $10 \mathrm{~T}_{\mathrm{GS}}$ & SEM & $\begin{array}{c}\text { C vs. } 5 U_{G S}+ \\
10 U_{G S}\end{array}$ & $\begin{array}{c}\text { C vs. } 5 T_{G S}+ \\
10 T_{G S}\end{array}$ & $\mathrm{U}_{\mathrm{GS}}$ vs. $\mathrm{T}_{\mathrm{GS}}$ \\
\hline Head & 8.76 & 8.35 & 8.39 & 8.65 & 8.76 & 0.17 & 0.100 & 0.793 & 0.100 \\
\hline LHW & 2.30 & 2.21 & 2.09 & 2.30 & 2.13 & 0.09 & 0.156 & 0.402 & 0.469 \\
\hline Liver & 6.61 & 6.36 & 6.46 & 6.17 & 6.58 & 0.33 & 0.611 & 0.553 & 0.917 \\
\hline Kidneys & 1.39 & 1.41 & 1.27 & 1.26 & 1.30 & 0.06 & 0.517 & 0.172 & 0.373 \\
\hline Perirenal fat & 1.74 & 1.77 & 2.11 & 1.75 & 1.91 & 0.13 & 0.209 & 0.558 & 0.407 \\
\hline Scapular fat & 0.81 & 0.72 & 0.84 & 0.80 & 0.74 & 0.04 & 0.590 & 0.431 & 0.780 \\
\hline Dissectible fat ${ }^{1}$ & 3.18 & 3.28 & 3.60 & 3.34 & 3.30 & 0.17 & 0.231 & 0.518 & 0.496 \\
\hline \multicolumn{10}{|l|}{ As \% of RCW: } \\
\hline Fore part & 38.9 & 40.0 & 38.0 & 38.5 & 39.2 & 0.82 & 0.901 & 0.989 & 0.866 \\
\hline Intermediate part & 27.3 & 26.1 & 26.7 & 26.2 & 26.9 & 0.69 & 0.299 & 0.369 & 0.861 \\
\hline Hind part & 40.5 & 39.8 & 39.9 & 39.5 & 39.8 & 0.45 & 0.280 & 0.156 & 0.670 \\
\hline Longissimus muscle & 3.83 & 3.66 & 3.77 & 3.54 & 3.81 & 0.08 & 0.241 & 0.122 & 0.638 \\
\hline Pelvic fat & 3.80 & 3.76 & 3.98 & 3.44 & 3.96 & 0.27 & 0.827 & 0.757 & 0.520 \\
\hline
\end{tabular}

C: control diet without grape stalks incorporation; $10 \mathrm{U}_{\mathrm{GS}}, 5 \mathrm{U}_{\mathrm{GS}}$ : diets with the incorporation of $100 \mathrm{and} 50 \mathrm{~g} / \mathrm{kg}$ of untreated grape stalks, respectively; $10 \mathrm{~T}_{\mathrm{GS}}, 5 \mathrm{~T}_{\mathrm{GS}}$ : diets with the incorporation of 100 and $50 \mathrm{~g} / \mathrm{kg}$ of treated grape stalks with L. edodes, respectively; SEM: standard error of the mean; L*: Lightness; $a^{*}$ : Redness; $b^{*}$. Yellowness LHW: Thymus, trachea, oesophagus, lungs, and heart; ${ }^{1}$ : Scapular, inguinal and perirenal fat. Differences were considered statistically significant at $p \leq 0.05$.

Table 3. Effect of the experimental diets on coefficients of total tract apparent digestibility (CTTAD, $n=6)$ and intestinal morphology of growing rabbits $(n=10)$. Effect of the experimental diets on growth performance and carcass traits $(n=10)$.

\begin{tabular}{|c|c|c|c|c|c|c|c|c|c|}
\hline & \multicolumn{5}{|c|}{ Experimental Diets } & \multicolumn{4}{|c|}{$p$-Value } \\
\hline & $\mathrm{C}$ & $5 \mathrm{U}_{\mathrm{GS}}$ & $10 U_{G S}$ & $5 T_{G S}$ & $10 \mathrm{~T}_{\mathrm{GS}}$ & SEM & $\begin{array}{l}\text { C vs. } 5 U_{G S} \\
+10 U_{G S}\end{array}$ & $\begin{array}{l}\text { C vs. } 5 \mathrm{~T}_{\mathrm{GS}} \\
+10 \mathrm{~T}_{\mathrm{GS}}\end{array}$ & $\mathrm{U}_{\mathrm{GS}}$ vs. $\mathrm{T}_{\mathrm{GS}}$ \\
\hline \multicolumn{10}{|l|}{ CTTAD $(n=6)$} \\
\hline Dry matter & 0.62 & 0.59 & 0.59 & 0.60 & 0.59 & 0.01 & 0.078 & 0.120 & 0.561 \\
\hline Organic matter & 0.62 & 0.59 & 0.60 & 0.60 & 0.59 & 0.012 & 0.102 & 0.180 & 0.731 \\
\hline NDFom & 0.32 & 0.32 & 0.31 & 0.32 & 0.32 & 0.013 & 0.409 & 0.710 & 0.597 \\
\hline Crude protein & 0.62 & 0.62 & 0.60 & 0.61 & 0.59 & 0.017 & 0.572 & 0.348 & 0.648 \\
\hline Crude Fat & 0.86 & 0.85 & 0.85 & 0.86 & 0.87 & 0.010 & 0.308 & 0.719 & 0.111 \\
\hline \multicolumn{10}{|c|}{ Intestinal morphology $(n=10)$} \\
\hline \multicolumn{10}{|c|}{ Duodenum $(\mu \mathrm{m})$} \\
\hline Villus height & 1086.6 & 1137.0 & 1105.2 & 1110.0 & 1097.0 & 65.6 & 0.668 & 0.834 & 0.788 \\
\hline Villus tip width & 117.0 & 125.4 & 117.6 & 119.4 & 117.3 & 4.44 & 0.417 & 0.806 & 0.487 \\
\hline Crypt depth & 332.5 & 329.3 & 353.1 & 309.2 & 337.3 & 30.4 & 0.816 & 0.804 & 0.557 \\
\hline $\mathrm{VH} / \mathrm{CD}^{1}$ & 3.52 & 3.82 & 3.25 & 3.70 & 3.53 & 0.37 & 0.960 & 0.819 & 0.826 \\
\hline Muscle layer & 215.3 & 191.0 & 187.1 & 195.9 & 174.7 & 14.6 & 0.148 & 0.100 & 0.800 \\
\hline \multicolumn{10}{|l|}{ Jejune $(\mu \mathrm{m})$} \\
\hline Villus height & 858.6 & 915.0 & 824.7 & 825.1 & 949.2 & 42.4 & 0.829 & 0.585 & 0.685 \\
\hline Villus tip width & 118.9 & 125.6 & 118.4 & 120.3 & 126.5 & 5.42 & 0.639 & 0.500 & 0.800 \\
\hline Crypt depth & 195.6 & 219.8 & 214.7 & 191.7 & 198.1 & 12.6 & 0.167 & 0.963 & 0.100 \\
\hline $\mathrm{VH} / \mathrm{CD}$ & 4.50 & 4.26 & 3.98 & 4.38 & 4.85 & 0.26 & 0.248 & 0.711 & 0.110 \\
\hline Muscle layer & 196.6 & 163.8 & 177.9 & 186.1 & 163.0 & 11.3 & 0.069 & 0.117 & 0.746 \\
\hline \multicolumn{10}{|l|}{ Ileum $(\mu \mathrm{m})$} \\
\hline Villus height & 685.6 & 634.2 & 571.7 & 597.1 & 591.9 & 43.3 & 0.127 & 0.093 & 0.847 \\
\hline Villus tip width & 119.3 & 118.8 & 111.0 & 119.6 & 126.2 & 5.50 & 0.518 & 0.595 & 0.153 \\
\hline Crypt depth & 197.5 & 221.8 & 164.1 & 208.5 & 172.5 & 27.0 & 0.891 & 0.833 & 0.928 \\
\hline $\mathrm{VH} / \mathrm{CD}$ & 3.68 & 3.14 & 3.51 & 3.22 & 3.58 & 0.27 & 0.284 & 0.396 & 0.781 \\
\hline Muscle layer & 238.9 & 225.2 & 283.1 & 218.9 & 248.7 & 18.0 & 0.492 & 0.818 & 0.264 \\
\hline
\end{tabular}


Table 4. Effect of the experimental diets on $\mathrm{pH}$ of caecal content and stomach, gastrointestinal tract physiology, and total concentration and profile of volatile fatty acids $(n=10)$.

\begin{tabular}{|c|c|c|c|c|c|c|c|c|c|}
\hline & \multicolumn{5}{|c|}{ Experimental Diets } & \multicolumn{4}{|c|}{$p$-Value } \\
\hline & $\mathrm{C}$ & $5 \mathbf{U}_{\mathrm{GS}}$ & $10 U_{G S}$ & $5 T_{G S}$ & $10 \mathrm{~T}_{\mathrm{GS}}$ & SEM & $\begin{array}{c}\text { C vs. } 5 U_{G S} \\
+10 U_{G S}\end{array}$ & $\begin{array}{l}\text { C vs. } 5 \mathrm{~T}_{\mathrm{GS}} \\
+10 \mathrm{~T}_{\mathrm{GS}}\end{array}$ & $\mathrm{U}_{\mathrm{GS}}$ vs. $\mathrm{T}_{\mathrm{GS}}$ \\
\hline pH Caecal content & 5.93 & 5.79 & 5.97 & 5.74 & 5.91 & 0.06 & 0.443 & 0.119 & 0.323 \\
\hline pH Stomach & 1.86 & 1.66 & 1.68 & 1.49 & 1.72 & 0.12 & 0.220 & 0.107 & 0.624 \\
\hline \multicolumn{10}{|l|}{ As $\%$ of HCW: } \\
\hline Full caecum & 10.6 & 10.1 & 10.5 & 10.9 & 10.4 & 0.55 & 0.734 & 0.947 & 0.620 \\
\hline Empty caecum & 2.71 & 2.57 & 2.71 & 2.53 & 2.55 & 0.12 & 0.646 & 0.246 & 0.387 \\
\hline Stomach & 7.37 & 8.57 & 8.41 & 7.91 & 9.26 & 0.52 & 0.086 & 0.063 & 0.853 \\
\hline Small Intestine & 8.46 & 8.35 & 8.13 & 8.71 & 8.17 & 0.38 & 0.639 & 0.967 & 0.598 \\
\hline Colon & 3.06 & 2.74 & 2.91 & 2.91 & 3.18 & 0.21 & 0.360 & 0.961 & 0.288 \\
\hline \multicolumn{10}{|l|}{ Length $(\mathrm{cm})$ : } \\
\hline Appendix Ceacal & 12.6 & 12.9 & 12.8 & 13.2 & 12.4 & 0.38 & 0.583 & 0.583 & 1.000 \\
\hline Caecum & 50.1 & 49.6 & 50.0 & 53.2 & 51.8 & 1.07 & 0.665 & 0.072 & 0.015 \\
\hline Small Intestine & 373.6 & 363.9 & 367.0 & 389.0 & 382.6 & 8.48 & 0.436 & 0.246 & 0.021 \\
\hline Colon & 37.8 & 38.0 & 39.3 & 40.8 & 37.9 & 1.18 & 0.562 & 0.292 & 0.559 \\
\hline Total VFA (mmol/100 mL) & 9.93 & 10.5 & 10.2 & 8.75 & 9.36 & 0.53 & 0.537 & 0.183 & 0.020 \\
\hline \multicolumn{10}{|l|}{ VFA profile ( $\%$ of total VFA) } \\
\hline Acetic acid & 76.2 & 76.1 & 78.7 & 74.0 & 75.6 & 0.86 & 0.268 & 0.194 & 0.005 \\
\hline Propionic acid & 5.30 & 4.78 & 5.09 & 5.14 & 5.39 & 0.28 & 0.279 & 0.918 & 0.231 \\
\hline Butyric acid & 18.0 & 18.6 & 15.9 & 20.3 & 18.4 & 0.80 & 0.447 & 0.211 & 0.016 \\
\hline Valeric acid & 0.47 & 0.52 & 0.38 & 0.49 & 0.58 & 0.09 & 0.809 & 0.586 & 0.337 \\
\hline
\end{tabular}

C: control diet without grape stalks incorporation; $10 \mathrm{U}_{\mathrm{GS}}, 5 \mathrm{U}_{\mathrm{GS}}$ : diets with the incorporation of 100 and $50 \mathrm{~g} / \mathrm{kg}$ of untreated grape stalks, respectively; $10 \mathrm{~T}_{\mathrm{GS}}, 5 \mathrm{~T}_{\mathrm{GS}}$ : diets with the incorporation of 100 and $50 \mathrm{~g} / \mathrm{kg}$ of treated grape stalks with L. edodes, respectively; SEM: standard error of the mean; HCW: Hot Carcass Weight; VFA: volatile fatty acids. Differences were considered statistically significant at $p \leq 0.05$.

Table 5. Effect of the experimental diets on blood hematology and serum biochemistry $(n=10)$.

\begin{tabular}{|c|c|c|c|c|c|c|c|c|c|}
\hline & \multicolumn{5}{|c|}{ Experimental Diets } & \multicolumn{4}{|c|}{$p$-Value } \\
\hline & $\mathrm{C}$ & $5 \mathbf{U}_{\mathrm{GS}}$ & $10 U_{G S}$ & $5 \mathrm{~T}_{\mathrm{GS}}$ & $10 \mathrm{~T}_{\mathrm{GS}}$ & SEM & $\begin{array}{c}\text { C vs. } 5 U_{G S} \\
+10 U_{G S}\end{array}$ & $\begin{array}{c}\text { C vs. } 5 \mathrm{~T}_{\mathrm{GS}} \\
+10 \mathrm{~T}_{\mathrm{GS}}\end{array}$ & $\mathrm{U}_{\mathrm{GS}}$ vs. $\mathrm{T}_{\mathrm{GS}}$ \\
\hline \multicolumn{10}{|l|}{ Haematology } \\
\hline Erythrocyte $(\mathrm{M} / \mu \mathrm{L})$ & 5.98 & 5.98 & 5.88 & 6.09 & 6.04 & 0.16 & 0.794 & 0.692 & 0.423 \\
\hline Haemoglobin (g/dL) & 11.9 & 12.3 & 11.9 & 12.2 & 12.3 & 0.30 & 0.587 & 0.251 & 0.455 \\
\hline Haematocrit (\%) & 37.9 & 38.8 & 37.5 & 38.4 & 39.3 & 0.94 & 0.846 & 0.445 & 0.485 \\
\hline Lymphocytes (\%) & 60.5 & 63.8 & 58.7 & 64.4 & 62.6 & 2.96 & 0.850 & 0.414 & 0.440 \\
\hline Monocytes (\%) & 7.43 & 7.41 & 7.83 & 8.48 & 7.75 & 0.66 & 0.816 & 0.404 & 0.460 \\
\hline Eosinophils (\%) & 0.96 & 0.70 & 0.95 & 0.94 & 0.88 & 0.15 & 0.453 & 0.780 & 0.563 \\
\hline Basophils (\%) & 5.08 & 4.28 & 5.61 & 5.16 & 4.38 & 0.51 & 0.831 & 0.624 & 0.735 \\
\hline Reticulocyte count (\%) & 3.32 & 2.97 & 2.72 & 2.91 & 3.50 & 0.25 & 0.126 & 0.708 & 0.155 \\
\hline \multicolumn{10}{|c|}{ Serum biochemistry (mg/dL) } \\
\hline Triglycerides & 82.9 & 78.4 & 73.4 & 66.2 & 67.6 & 3.34 & 0.084 & $<0.001$ & 0.005 \\
\hline Cholesterol & 42.7 & 42.7 & 39.3 & 35.5 & 37.9 & 2.64 & 0.591 & 0.071 & 0.117 \\
\hline Urea & 31.5 & 27.2 & 27.5 & 26.5 & 27.0 & 0.92 & 0.001 & $<0.001$ & 0.510 \\
\hline Creatinine & 0.75 & 0.75 & 0.59 & 0.75 & 0.75 & 0.05 & 0.227 & 0.652 & 0.122 \\
\hline AST & 32.0 & 31.9 & 29.5 & 38.1 & 31.6 & 3.52 & 0.694 & 0.390 & 0.129 \\
\hline Alanine & 31.7 & 39.8 & 33.6 & 33.8 & 34.5 & 4.04 & 0.318 & 0.623 & 0.531 \\
\hline Albumin & 3.48 & 3.21 & 3.10 & 3.14 & 3.52 & 0.20 & 0.206 & 0.554 & 0.405 \\
\hline Total protein & 4.54 & 4.75 & 4.47 & 4.55 & 4.56 & 0.09 & 0.507 & 0.886 & 0.523 \\
\hline
\end{tabular}

C: control diet without grape stalks incorporation; $10 \mathrm{U}_{\mathrm{GS}}, 5 \mathrm{U}_{\mathrm{GS}}$ : diets with the incorporation of $100 \mathrm{and} 50 \mathrm{~g} / \mathrm{kg}$ of untreated grape stalks, respectively; $10 \mathrm{~T}_{\mathrm{GS}}, 5 \mathrm{~T}_{\mathrm{Gs}}$ : diets with the incorporation of $100 \mathrm{and} 50 \mathrm{~g} / \mathrm{kg}$ of treated grape stalks with $L$. edodes, respectively; SEM: standard error of the mean; RDW: Red cell distribution width; AST: Aspartate aminotransferase. Differences were considered statistically significant at $p \leq 0.05$.

Triglycerides were lower on animals fed with $\mathrm{T}_{\mathrm{GS}}$ diets, showing a reduction of $-11.9 \%$ when compared to $\mathrm{U}_{\mathrm{GS}}$ diets $(p=0.005)$ and $-19.3 \%$ compared to the control diet $(p<0.001)$. A slight decrease $(p=0.084)$ in the triglycerides of the rabbits fed with $\mathrm{U}_{\mathrm{GS}}$ compared to 
the control diet was also detected $(-8.5 \%)$. Studies indicate that winery wastes could be a valuable source of antioxidants and other active bio compounds, such as polyphenols and dietary fibers [44], that can reduce triglyceride levels in the bloodstream. Animal studies have been mainly focused on the utilization of grape seed extracts as a source of compounds that could attenuate hyperlipidemic effects. In rabbits, studies have pointed out that grape seed extracts can lower plasma triglyceride concentrations [45].

The lipid-lowering and anti-hyperlipidemic activity are normally attributed to the inhibition of the oxidation process of the low-density lipoproteins [46,47] due to the high concentrations of antioxidants [48]. As the phenolic substances concentration and the antioxidant activity of grape stems used in this study $[49,50]$ are similar to the ones presented by grape seeds [51,52], it is feasible to assume that grape stems might also present the same anti-hyperlipidemic effects. Regarding urea, rabbits fed on $\mathrm{U}_{\mathrm{GS}}$ and $\mathrm{T}_{\mathrm{GS}}$ diets presented blood levels 13.5\% and 19.3\% lower than those fed on the control diet, respectively. Blood urea is the nitrogen content in urine from proteolysis, which occurs when energy production is insufficient to maintain the animals' energy requirements [53]. The urea levels are also inversely related to dietary protein quality, i.e., the lower the serum urea levels, the better the quality of protein in the feedstuff [54,55]. In theory, the increased production of urea by the liver released into the blood for further excretion could be due to an unbalanced diet of any essential amino acids that would catabolize the remaining amino acids [54]. Although the experimental diets showed similar levels of crude protein (Table 1), their protein source is not the same due to the incorporation of $\mathrm{T}_{\mathrm{GS}}$ and $\mathrm{U}_{\mathrm{GS}}$, and this might have changed the amino acid profiles.

The fatty acids (FA) profile of longissimus muscle present in Table 6 shows that the rabbits fed with $\mathrm{T}_{\mathrm{GS}}$ diets showed higher levels of linoleic acid (LA) when compared to the control diet $(p=0.016)$ and higher levels of $\gamma$-linolenic (GLA) when compared to the control diet $(p=0.026)$ and with $\mathrm{U}_{\mathrm{GS}}$ diets $(p=0.019)$. It is well known that the FA levels of the monogastric animals' meat are more susceptible to being manipulated through the diet since the FA are absorbed, unchanged, by the intestine and embedded tissues [56]. For example, linoleic acid, which plays an important role in functions such as cell physiology, immunity, and reproduction, is not synthesized de novo by animals and is thus required as a dietary source, given that concentrations present in the meat respond rapidly to changes in diet. In contrast, MUFAs and SFAs are synthesized and are less influenced by the diet than PUFAs [57]. Treatment with fungi on the grape stalks may have promoted an increase in LA and GLA since the deposition of these FA in meat is entirely derived from the diet. Fungi can produce a wide variety of lipids, with linoleic, oleic, and palmitic acids being the most reported fatty acids [58]. Some studies [59,60] already reported that L. edodes linoleic acid has the highest proportion in the lipid content (about $68 \%$ ), followed by palmitic acid $(16 \%)$ and oleic acid (5.5\%). In this way, the increase in GLA could have been promoted by its presence on mycelium in the diet where fungi-treated grape stalks were incorporated. The $\mathrm{T}_{\mathrm{GS}}$ diets also increased $\sum \omega-6, \sum \mathrm{PUFA}$, and ratio $\sum$ PUFA $/ \sum S F A$, as a result of the increase of LA and GLA. PUFAs, in particular $\omega-3$ and $\omega-6$, are very important in human health due to their multiple biological roles, such as influencing the inflammatory processes, reducing the oxidative stress, neuroprotection, and cardiovascular protection [61]. The fungal treatment may have enhanced different lipid profiles on the diets, promoting an increase in both PUFA and the ratio of PUFA to SFA. No differences were observed on the analyzed parameters for meat quality (Table 7), such as $\mathrm{pH}$, color, cooking losses, or even shear force. 
Table 6. Effect of the experimental diets on fatty acids profile of longissimus muscle $(\mathrm{g} / 100 \mathrm{~g}$ of fat; $n=10$ ).

\begin{tabular}{|c|c|c|c|c|c|c|c|c|c|}
\hline & \multicolumn{5}{|c|}{ Experimental Diets } & \multicolumn{4}{|c|}{$p$-Value } \\
\hline & $\mathrm{C}$ & $5 \mathrm{U}_{\mathrm{GS}}$ & $10 U_{\mathrm{GS}}$ & $5 T_{\mathrm{GS}}$ & $10 \mathrm{~T}_{\mathrm{GS}}$ & SEM & $\begin{array}{c}\text { C vs. } 5 U_{\mathrm{GS}}+ \\
10 \mathrm{U}_{\mathrm{GS}}\end{array}$ & $\begin{array}{c}\text { C vs. } 5 \mathrm{~T}_{\mathrm{GS}}+ \\
10 \mathrm{~T}_{\mathrm{GS}}\end{array}$ & $\mathrm{U}_{\mathrm{GS}}$ vs. $\mathrm{T}_{\mathrm{GS}}$ \\
\hline \multicolumn{10}{|l|}{ SFA } \\
\hline C4:0 & 0.10 & 0.11 & 0.12 & 0.12 & 0.11 & 0.01 & 0.484 & 0.357 & 0.785 \\
\hline C6:0 & 0.07 & 0.07 & 0.08 & 0.08 & 0.07 & 0 & 0.457 & 0.327 & 0.769 \\
\hline $\mathrm{C} 8: 0$ & 0.05 & 0.05 & 0.06 & 0.06 & 0.06 & 0 & 0.413 & 0.342 & 0.869 \\
\hline$C: 10$ & 0.11 & 0.12 & 0.12 & 0.12 & 0.11 & 0.01 & 0.447 & 0.431 & 0.973 \\
\hline C11:0 & 0.01 & 0.01 & 0.02 & 0.02 & 0.02 & 0 & 0.414 & 0.307 & 0.799 \\
\hline C12:0 & 0.63 & 0.58 & 0.58 & 0.64 & 0.6 & 0.03 & 0.21 & 0.756 & 0.247 \\
\hline $\mathrm{C} 13: 0$ & 0.02 & 0.02 & 0.02 & 0.02 & 0.02 & 0 & 0.715 & 0.276 & 0.372 \\
\hline C14:0 & 2.11 & 2.02 & 2.08 & 2.14 & 2.10 & 0.1 & 0.612 & 0.932 & 0.469 \\
\hline $\mathrm{C} 15: 0$ & 0.31 & 0.32 & 0.32 & 0.32 & 0.33 & 0.01 & 0.629 & 0.250 & 0.409 \\
\hline C16:0 & 18.23 & 18.2 & 18.97 & 18.43 & 18.16 & 0.58 & 0.615 & 0.927 & 0.614 \\
\hline C17:0 & 0.31 & 0.32 & 0.31 & 0.31 & 0.32 & 0.01 & 0.596 & 0.445 & 0.774 \\
\hline C18:0 & 3.69 & 3.76 & 3.75 & 3.74 & 3.64 & 0.11 & 0.626 & 0.988 & 0.563 \\
\hline C20:0 & 0.09 & 0.09 & 0.08 & 0.09 & 0.09 & 0 & 0.914 & 0.406 & 0.376 \\
\hline C21:0 & 0.02 & 0.02 & 0.02 & 0.02 & 0.02 & 0 & 0.962 & 0.233 & 0.162 \\
\hline C22:0 & 0.05 & 0.05 & 0.05 & 0.05 & 0.05 & 0 & 0.448 & 0.737 & 0.183 \\
\hline C23:0 & 0.08 & 0.08 & 0.08 & 0.09 & 0.08 & 0 & 0.665 & 0.796 & 0.831 \\
\hline C24:0 & 0.04 & 0.03 & 0.04 & 0.04 & 0.04 & 0 & 0.292 & 0.632 & 0.479 \\
\hline$\sum S F A$ & 25.92 & 25.84 & 26.70 & 26.30 & 25.79 & 0.79 & 0.723 & 0.898 & 0.782 \\
\hline \multicolumn{10}{|l|}{ MUFA } \\
\hline C14:1n-5 & 0.15 & 0.18 & 0.17 & 0.14 & 0.17 & 0.02 & 0.430 & 0.856 & 0.456 \\
\hline C15:1n-5 & 0.93 & 0.88 & 0.95 & 0.93 & 0.88 & 0.06 & 0.848 & 0.719 & 0.836 \\
\hline$C 16: 1 n-7$ & 1.82 & 1.99 & 2.14 & 1.73 & 1.97 & 0.20 & 0.318 & 0.909 & 0.279 \\
\hline C18:1n-9t & 0.12 & 0.13 & 0.13 & 0.13 & 0.13 & 0.01 & 0.546 & 0.342 & 0.670 \\
\hline C18:1n-11t & 0.20 & 0.21 & 0.23 & 0.23 & 0.22 & 0.01 & 0.228 & 0.076 & 0.470 \\
\hline C18:1n-9 & 16.18 & 16.56 & 15.81 & 16.98 & 15.98 & 0.55 & 0.989 & 0.656 & 0.598 \\
\hline C18:1n-7 & 0.76 & 0.77 & 0.79 & 0.79 & 0.76 & 0.02 & 0.517 & 0.704 & 0.741 \\
\hline C20:1n-9 & 0.17 & 0.17 & 0.16 & 0.18 & 0.16 & 0.01 & 0.505 & 0.962 & 0.448 \\
\hline C22:1n-9 & 0.03 & 0.03 & 0.03 & 0.03 & 0.03 & 0 & 0.488 & 0.761 & 0.633 \\
\hline$\sum M U F A$ & 20.37 & 20.93 & 20.4 & 21.13 & 20.31 & 0.71 & 0.738 & 0.691 & 0.937 \\
\hline \multicolumn{10}{|l|}{$\omega-3$ FA } \\
\hline C18:3n-3 & 0.83 & 0.85 & 0.87 & 0.82 & 0.83 & 0.03 & 0.400 & 0.959 & 0.334 \\
\hline$C 20: 3 n-3$ & 0.04 & 0.04 & 0.04 & 0.04 & 0.04 & 0 & 0.571 & 0.822 & 0.676 \\
\hline C20:5n-3 & 0.07 & 0.06 & 0.07 & 0.06 & 0.06 & 0 & 0.578 & 0.251 & 0.464 \\
\hline$C 22: 5 n-3$ & 0.36 & 0.35 & 0.37 & 0.35 & 0.35 & 0.02 & 0.808 & 0.672 & 0.825 \\
\hline C22:6n-3 & 0.08 & 0.08 & 0.08 & 0.09 & 0.08 & 0.01 & 0.814 & 0.739 & 0.903 \\
\hline$\sum w-3$ & 1.38 & 1.39 & 1.41 & 1.36 & 1.37 & 0.03 & 0.548 & 0.792 & 0.291 \\
\hline \multicolumn{10}{|l|}{$\omega-6$ FA } \\
\hline C18:2n-6 & 17.76 & 18.93 & 18.54 & 19.58 & 19.44 & 0.57 & 0.171 & 0.016 & 0.182 \\
\hline$C 18: 3 n-6$ & 0.08 & 0.08 & 0.08 & 0.09 & 0.09 & 0 & 0.757 & 0.026 & 0.019 \\
\hline$C 20: 2 n-6$ & 0.29 & 0.29 & 0.29 & 0.32 & 0.29 & 0.01 & 0.912 & 0.368 & 0.218 \\
\hline$C 20: 3 n-6$ & 0.27 & 0.27 & 0.27 & 0.29 & 0.27 & 0.02 & 0.706 & 0.400 & 0.568 \\
\hline C20:4n-6 & 2.61 & 2.66 & 2.62 & 2.85 & 2.65 & 0.17 & 0.896 & 0.523 & 0.534 \\
\hline$\sum \omega-6$ & 21.00 & 22.23 & 21.81 & 23.13 & 22.74 & 0.63 & 0.200 & 0.017 & 0.157 \\
\hline \multicolumn{10}{|l|}{ Other PUFA } \\
\hline $\mathrm{C} 18: 2 \mathrm{n}-9 \mathrm{c}, 11 \mathrm{t}$ & 0.16 & 0.17 & 0.19 & 0.18 & 0.17 & 0 & 0.285 & 0.199 & 0.786 \\
\hline$\sum P U F A$ & 22.55 & 23.78 & 23.41 & 24.68 & 24.28 & 0.66 & 0.203 & 0.022 & 0.189 \\
\hline$\sum$ PUFA/ $\sum$ SFA & 0.87 & 0.92 & 0.88 & 0.94 & 0.94 & 0.02 & 0.292 & 0.014 & 0.072 \\
\hline$\sum \mathrm{FA}$ & 68.84 & 70.55 & 70.51 & 72.11 & 70.38 & 1.93 & 0.479 & 0.315 & 0.712 \\
\hline
\end{tabular}


Table 7. Effect of the experimental diets on parameters of meat quality of longissimus muscle $(n=10)$.

\begin{tabular}{|c|c|c|c|c|c|c|c|c|c|}
\hline & \multicolumn{6}{|c|}{ Experimental Diets } & \multicolumn{3}{|c|}{$p$-Value } \\
\hline & $\mathrm{C}$ & $5 \mathrm{U}_{\mathrm{GS}}$ & $10 U_{\mathrm{GS}}$ & $5 \mathrm{~T}_{\mathrm{GS}}$ & $10 \mathrm{~T}_{\mathrm{GS}}$ & SEM & $\begin{array}{c}\text { C vs. } 5 U_{G S}+ \\
10 U_{G S}\end{array}$ & $\begin{array}{c}\text { C vs. } 5 \mathrm{~T}_{\mathrm{GS}}+ \\
10 \mathrm{~T}_{\mathrm{GS}}\end{array}$ & $\mathrm{U}_{\mathrm{GS}}$ vs. $\mathrm{T}_{\mathrm{GS}}$ \\
\hline $\mathrm{pH}_{48}$ & 5.60 & 5.61 & 5.62 & 5.63 & 5.62 & 0.02 & 0.532 & 0.274 & 0.561 \\
\hline \multicolumn{10}{|l|}{ Meat color } \\
\hline$L^{*}$ & 59.6 & 59.5 & 59.1 & 60.2 & 59.3 & 0.73 & 0.726 & 0.868 & 0.527 \\
\hline$a^{*}$ & 0.01 & 0.23 & 0.29 & 0.18 & 0.19 & 0.25 & 0.413 & 0.566 & 0.763 \\
\hline$b^{*}$ & 9.78 & 9.61 & 9.54 & 10.2 & 9.86 & 0.23 & 0.475 & 0.394 & 0.059 \\
\hline Cooking losses (\%) & 30.3 & 30.0 & 30.7 & 29.5 & 30.9 & 0.79 & 0.981 & 0.907 & 0.863 \\
\hline Shear force & 25.8 & 21.8 & 24.6 & 25.5 & 24.3 & 1.27 & 0.087 & 0.561 & 0.161 \\
\hline
\end{tabular}

C: control diet without grape stalks incorporation; 10UGS, 5UGS: diets with the incorporation of $100 \mathrm{and} 50 \mathrm{~g} / \mathrm{kg}$ of untreated grape stalks, respectively; 10TGS, 5TGS: diets with the incorporation of 100 and $50 \mathrm{~g} / \mathrm{kg}$ of treated grape stalks with L. edodes, respectively; SEM: standard error of the mean; $\mathrm{pH} 48$ : $\mathrm{pH}$ measured $48 \mathrm{~h}$ after slaughter; $L^{*}$ : Lightness; $a^{*}$ : Redness; $b^{*}$. Yellowness.

\section{Conclusions}

In summary, grape stalks ( $\mathrm{U}_{\mathrm{GS}}$ and $\mathrm{T}_{\mathrm{GS}}$ ) could be effectively used as an alternative raw material in rabbits' diets, representing a good strategy to optimize the use of winery by-products while maintaining animal performance. Fungi-treated grape stalks can provide some improvements, such as a decrease in plasma lipids in the bloodstream and an increase in fatty acids in rabbits' meat, beneficial for human consumption. However, further studies with a greater number of animals are needed reinforce the obtained results and to understand specific metabolic routes due to the presence of fungal mycelium and their nutraceutical proprieties on rabbit nutrition.

Author Contributions: Conceptualization, V.C.-S., M.R. and L.F.; methodology, V.C.-S., M.R. and L.F.; software, V.C.-S.; validation, M.R. and L.F.; formal analysis, V.C.-S., A.A., J.A.S. and J.L.; investigation, V.C.-S.; resources, V.P. and G.M.; data curation, V.C.-S. and M.R.; writing—original draft preparation, V.C.-S.; writing - review and editing, M.R. and L.F.; funding acquisition, G.M. and L.F. All authors have read and agreed to the published version of the manuscript.

Funding: This research was funded by European Social Fund FSE, grant number NORTE-08-5369FSE-000040" and was also supported by the project FungiTech, Norte-01-0247-FEDER-033788 and by European Investment Funds by FEDER/COMPETE/POCI- Operational Competitiveness and Internationalization Programme, under the Project POCI-01-0145-FEDER-006958 and National Funds by FCT-Portuguese Foundation for Science and Technology, under the project UIDB04033/2020.

Institutional Review Board Statement: The study was conducted according to the Portuguese legislation (Ports. no. 1005/92, 214/08, 635/09) on animal welfare. The ethical committee of the University of Trás-os-Montes and Alto Douro (ORBEA, Animal Welfare Authority) approved the experimental protocol (Process number: 1058-e-DZ-2019).

Informed Consent Statement: Not applicable.

Data Availability Statement: The data are contained within the article.

Acknowledgments: Valéria Costa-Silva holds a grant from the Animal Science Doctoral Program (AniSci), operation number NORTE-08-5369-FSE-000040, co-funded by the European Social Fund FSE and through National funds NORTE 2020 and Regional Operacional Program of North 2014/2020.

Conflicts of Interest: The authors declare no conflict of interest.

\section{References}

1. Falcone, D.B.; Klinger, A.C.K.; de Toledo, G.S.P.; da Silva, L.P. Performance, meat characteristics and economic viability of rabbits fed diets containing banana peel. Trop. Anim. Health Prod. 2020, 52, 681-685. [CrossRef]

2. Gidenne, T.; Garreau, H.; Drouilhet, L.; Aubert, C.; Maertens, L. Improving feed efficiency in rabbit production, a review on nutritional, technico-economical, genetic and environmental aspects. Anim. Feed Sci. Technol. 2017, 225, 109-122. [CrossRef]

3. Da Ros, C.; Cavinato, C.; Bolzonella, D.; Pavan, P. Renewable energy from thermophilic anaerobic digestion of winery residue: Preliminary evidence from batch and continuous lab-scale trials. Biomass Bioenergy 2016, 91, 150-159. [CrossRef] 
4. Prozil, S.O.; Evtuguin, D.V.; Lopes, L.P.C. Chemical composition of grape stalks of Vitis vinifera L. from red grape pomaces. Ind. Crops Prod. 2012, 35, 178-184. [CrossRef]

5. Spigno, G.; Marinoni, L.; Garrido, G.D. State of the Art in Grape Processing By-Products; Elsevier Inc.: Amsterdam, The Netherlands, 2017; ISBN 9780128098714.

6. $\quad$ Fernandes, J.M.C.; Fraga, I.; Sousa, R.M.O.F.; Rodrigues, M.A.M.; Sampaio, A.; Bezerra, R.M.F.; Dias, A.A. Pretreatment of grape stalks by fungi: Effect on bioactive compounds, fiber composition, saccharification kinetics and monosaccharides ratio. Int. J. Environ. Res. Public Health 2020, 17, 5900. [CrossRef] [PubMed]

7. Llobera, A.; Cañellas, J. Dietary fibre content and antioxidant activity of Manto Negro red grape (Vitis vinifera): Pomace and stem. Food Chem. 2007, 101, 659-666. [CrossRef]

8. González-Centeno, M.R.; Rosselló, C.; Simal, S.; Garau, M.C.; López, F.; Femenia, A. Physico-chemical properties of cell wall materials obtained from ten grape varieties and their byproducts: Grape pomaces and stems. LWT-Food Sci. Technol. 2010, 43, 1580-1586. [CrossRef]

9. Spigno, G.; Pizzorno, T.; De Faveri, D.M. Cellulose and hemicelluloses recovery from grape stalks. Bioresour. Technol. 2008, 99, $4329-4337$. [CrossRef]

10. van Kuijk, S.J.A.; Sonnenberg, A.S.M.; Baars, J.J.P.; Hendriks, W.H.; Cone, J.W. Fungal treated lignocellulosic biomass as ruminant feed ingredient: A review. Biotechnol. Adv. 2015, 33, 191-202. [CrossRef]

11. Pérez, J.; Muñoz-Dorado, J.; De La Rubia, T.; Martínez, J. Biodegradation and biological treatments of cellulose, hemicellulose and lignin: An overview. Int. Microbiol. 2002, 5, 53-63. [CrossRef]

12. Calzada, J.F.; Franco, L.F.; de Arriola, M.C.; Rolz, C.; Ortiz, M.A. Acceptability, body weight changes and digestibility of spent wheat straw after harvesting of Pleurotus sajor-caju. Biol. Wastes 1987, 22, 303-309. [CrossRef]

13. Fazaeli, H.; Masoodi, A.R.T. Spent wheat straw compost of Agaricus bisporus mushroom as ruminant feed. Asian-Australas. J. Anim. Sci. 2006, 19, 845-851. [CrossRef]

14. Misra, A.K.; Mishra, A.S.; Tripathi, M.K.; Prasad, R.; Vaithiyanathan, S.; Jakhmola, R.C. Optimization of Solid State Fermentation of Mustard (Brassica campestris) Straw for Production of Animal Feed by White Rot Fungi (Ganoderma lucidum ). Asian-Australas. J. Anim. Sci. 2007, 20, 208-213. [CrossRef]

15. Zhao, X.; Gong, J.; Zhou, S.; Ouyang, K.; Song, X.; Fu, C.; Xu, L.; Qu, M. Effect of Fungal Treatments of Rape Straw on Chemical Composition and in vitro Rumen Fermentation Characteristics. BioResourses 2015, 10, 622-637. [CrossRef]

16. Xiang, H.; Zhao, X.; Fang, Y.; Wang, F.; Liang, R.; Sun, X.; Wang, S.; Zhong, R. Feeding Fungal-Pretreated Corn Straw Improves Health and Meat Quality of Lambs Infected with Gastrointestinal Nematodes. Animals 2020, 10, 1659. [CrossRef] [PubMed]

17. Fazaeli, H.; Jelan, Z.A.; Mahmodzadeh, H.; Liang, J.B.; Azizi, A.; Osman, A. Effect of fungal treated wheat straw on the diet of lactating cows. Asian-Australas. J. Anim. Sci. 2002, 15, 1573-1578. [CrossRef]

18. Fazaeli, H.; Shafyee-Varzeneh, H.; Farahpoor, A.; Moayyer, A. Recycling of mushroom compost wheat straw in the diet of feedlot calves with two physical forms. Int. J. Recycl. Org. Waste Agric. 2014, 3, 3. [CrossRef]

19. Shrivastava, B.; Jain, K.K.; Kalra, A.; Kuhad, R.C. nutritionally rich and digested cattle feed. Scientific Reports 2014, 4, 1-9. [CrossRef]

20. Khonkhaeng, B.; Cherdthong, A. Pleurotus ostreatus and Volvariella volvacea can enhance the quality of purple field corn stover and modulate ruminal fermentation and feed utilization in tropical beef cattle. Animals 2019, 9, 1084. [CrossRef]

21. Ribeiro, L.; Pinheiro, V.; Outor-Monteiro, D.; Mourão, J.; Bezerra, R.M.F.; Dias, A.A.; Bennett, R.N.; Marques, G.; Rodrigues, M.A.M. Effects of the dietary incorporation of untreated and white-rot fungi (Ganoderma resinaceum Boud) pre-treated olive leaves on growing rabbits. Anim. Feed Sci. Technol. 2012, 173, 244-251. [CrossRef]

22. El-fallal, A.A.; El-Dein, M.M.N.; El-Maaty, H.M.A.A.; Awad, F.F. Effect of Biologically Treated Wheat Straw with White-Rot Fungi on Performance, Digestibility and Oxidative Status of Rabbits. Pak. J. Biol. Sci. PJBS 2020, 23, 1551-1562. [CrossRef] [PubMed]

23. Andrade, E.; Pinheiro, V.; Costa-Silva, V.; Marques, G.; Alves, A.; Serra, C.; Cone, J.W.; Saavedra, M.J.; Barros, A.; Ferreira, L.; et al Incorporation of untreated or white-rot fungi treated cowpea stover on performance, digestibility, health and meat quality of growing rabbits. Anim. Feed Sci. Technol. 2021, 281, 115100. [CrossRef]

24. De Blas, C.; Mateos, G. Feed Formulation, 2nd ed.; De Blas, C., Wiseman, J., Eds.; CABI: Oxfordshire, UK, $2010 ;$ ISBN 9783540773405.

25. Perez, J.M.; Lebas, F.; Gidenne, T.; Maertens, L.; Xiccato, G.; Parigi-Bini, R.; Dalle Zotte, A.; Cossu, M.E.; Carazzolo, A.; Villamide, M.J.; et al. European reference method for in vivo determination of diet digestibility in rabbits. World Rabbit Sci. 1995, 3, 41-43.

26. AOAC Official Methods of Analysis (20th edn). Assoc. Off. Anal. Chem. Arlingt. VA 2016, 1, 70. [CrossRef]

27. Van Soest, P.J.; Robertson, J.B. Systems of Analysis for Evaluating Fibrous Feeds. Stand. Anal. Methodol. Feed. 1980, 4, 49-60.

28. Van Soest, P.J.; Robertson, J.B.; Lewis, B.A. Methods for Dietary Fiber, Neutral Detergent Fiber, and Nonstarch Polysaccharides in Relation to Animal Nutrition. J. Dairy Sci. 1991, 74, 3583-3597. [CrossRef]

29. Blasco, A.; Ouhayoun, J. Harmonization of criteria and terminology in rabbit meat research: Pevised proposal. World Rabbit Sci. 1993, 4, 93-99. [CrossRef]

30. Czerkawski, J.W. The use of pivalic acid as a reference substance in measurements of production of volatile fatty acids by rumen micro-organisms in vitro. Br. J. Nutr. 1976, 36, 311-315. [CrossRef]

31. Gamble, M. The Hematoxylins and Eosin. In Theory and Practice of Histological Techniques (Sixth Edition); Bancroft, J.D., Gamble, M., Eds.; Churchill Livingstone: Edinburgh, UK, 2008; pp. 121-134, ISBN 978-0-443-10279-0. 
32. Ouhayoun, J.; Dalle Zotte, A. Harmonization of Muscle and Meat Criteria in Rabbit Meat Research. World Rabbit Sci. 1996, 4, 211-218. [CrossRef]

33. Bligh, E.G.; Dyer, W.J. A rapid method of total lipid extraction and purification. Can. J. Biochem. Physiol. 1959, 37, 911-917. [CrossRef] [PubMed]

34. Barros, J.C.; Munekata, P.E.S.; De Carvalho, F.A.L.; Pateiro, M.; Barba, F.J.; Domínguez, R.; Trindade, M.A.; Lorenzo, J.M. Use of tiger nut (Cyperus esculentus L.) oil emulsion as animal fat replacement in beef burgers. Foods 2020, 9, 44. [CrossRef]

35. Domínguez, R.; Borrajo, P.; Lorenzo, J.M. The effect of cooking methods on nutritional value of foal meat. J. Food Compos. Anal. 2015, 43, 61-67. [CrossRef]

36. Munekata, P.E.S.; Pateiro, M.; Domínguez, R.; Zhou, J.; Barba, F.J.; Lorenzo, J.M. Nutritional characterization of sea bass processing by-products. Biomolecules 2020, 10, 232. [CrossRef] [PubMed]

37. Abd-El Ghanya, F.T.F.; Salamaa, W.A.; Younana, G.E.; Shamesldeena, A.E.; El-Shoraa, M.A.; Perisb, S.I.; Mahrosec, K.M. Efficacy of dietary inclusion of biologically treated pruning peach trees by-products on growth performance, blood biochemicals and economic efficiency of New Zealand White rabbits. Anim. Biotechnol. 2021. [CrossRef] [PubMed]

38. El-Kady, R.I.; Morad, A.A.A.; Abedo, A.A.; El-Shahat, A.A. Effect of feeding rabbits on fungal treated corn stalks on carcass characteristics and meat composition. Bull. Natl. Res. Cent. 2019, 43, 77. [CrossRef]

39. Omer, H.A.A.; Ahmed, S.M.; El-kady, R.I.; El-shahat, A.A.; El-ayek, M.Y.; El-nattat, W.S.; Morad, A.A.A. Nutritional impact of partial or complete replacement of clover hay by untreated or biologically treated rice straw and corn stalks on: 1. growth performance and economic evaluation of growing New Zealand (NZW) White rabbits. Bull. Natl. Res. Cent. 2019, 43, 192. [CrossRef]

40. Biasato, I.; Ferrocino, I.; Biasibetti, E.; Grego, E.; Dabbou, S.; Sereno, A.; Gai, F.; Gasco, L.; Schiavone, A.; Cocolin, L.; et al. Modulation of intestinal microbiota, morphology and mucin composition by dietary insect meal inclusion in free-range chickens. BMC Vet. Res. 2018, 14, 383. [CrossRef]

41. Tufarelli, V.; Desantis, S.; Zizza, S.; Laudadio, V. Performance, gut morphology and carcass characteristics of fattening rabbits as affected by particle size of pelleted diets. Arch. Anim. Nutr. 2010, 64, 373-382. [CrossRef] [PubMed]

42. Carabaño, R.; Piquer, J.; Menoyo, D.; Badiola, I. The Digestive System of the Rabbit. In Nutrition of the Rabbit; De Blas, C., Wiseman, J., Eds.; CABI Publishing: Wallingford, UK, 2010; pp. 1-18, ISBN 9781845936693.

43. Margüenda, I.; Nicodemus, N.; Vadillo, S.; Sevilla, L.; García-Rebollar, P.; Villarroel, M.; Romero, C.; Carabaño, R. Effect of dietary type and level of fibre on rabbit carcass yield and its microbiological characteristics. Livest. Sci. 2012, 145, 7-12. [CrossRef]

44. Troilo, M.; Difonzo, G.; Paradiso, V.M.; Summo, C.; Caponio, F. Bioactive compounds from vine shoots, grape stalks, and wine lees: Their potential use in agro-food chains. Foods 2021, 10, 342. [CrossRef]

45. Hassan, F.A.; Mahrose, K.M.; Basyony, M.M. Effects of grape seed extract as a natural antioxidant on growth performance, carcass characteristics and antioxidant status of rabbits during heat stress. Arch. Anim. Nutr. 2016, 70, 141-154. [CrossRef]

46. Adisakwattana, S.; Moonrat, J.; Srichairat, S.; Chanasit, C.; Tirapongporn, H.; Chanathong, B.; Ngamukote, S.; Mäkynen, K.; Sapwarobol, S. Lipid-lowering mechanisms of grape seed extract (Vitis vinifera L) and its antihyperlidemic activity. J. Med. Plants Res. 2010, 4, 2113-2120.

47. Teissedre, P.L.; Waterhouse, A.L. Inhibition of oxidation of human low-density lipoproteins by phenolic substances in different essential oils varieties. J. Agric. Food Chem. 2000, 48, 3801-3805. [CrossRef] [PubMed]

48. Akbari, M.; Torki, M. Effects of dietary chromium picolinate and peppermint essential oil on growth performance and blood biochemical parameters of broiler chicks reared under heat stress conditions. Int. J. Biometeorol. 2014, 58, 1383-1391. [CrossRef]

49. Leal, C.; Gouvinhas, I.; Santos, R.A.; Rosa, E.; Silva, A.M.; Saavedra, M.J.; Barros, A.I.R.N.A. Potential application of grape (Vitis vinifera L.) stem extracts in the cosmetic and pharmaceutical industries: Valorization of a by-product. Ind. Crops Prod. 2020, $154,112675$. [CrossRef]

50. Gouvinhas, I.; Santos, R.A.; Queiroz, M.; Leal, C.; Saavedra, M.J.; Domínguez-Perles, R.; Rodrigues, M.; Barros, A.I.R.N.A Monitoring the antioxidant and antimicrobial power of grape (Vitis vinifera L.) stems phenolics over long-term storage. Ind. Crops Prod. 2018, 126, 83-91. [CrossRef]

51. Rockenbach, I.I.; Rodrigues, E.; Gonzaga, L.V.; Caliari, V.; Genovese, M.I.; Gonalves, A.E.D.S.S.; Fett, R. Phenolic compounds content and antioxidant activity in pomace from selected red grapes (Vitis vinifera L. and Vitis labrusca L.) widely produced in Brazil. Food Chem. 2011, 127, 174-179. [CrossRef]

52. Farhadi, K.; Esmaeilzadeh, F.; Hatami, M.; Forough, M.; Molaie, R. Determination of phenolic compounds content and antioxidant activity in skin, pulp, seed, cane and leaf of five native grape cultivars in West Azerbaijan province, Iran. Food Chem. 2016, 199, 847-855 [CrossRef]

53. Geng, P.; Siu, K.C.; Wang, Z.; Wu, J.Y. Antifatigue Functions and Mechanisms of Edible and Medicinal Mushrooms. Biomed Res. Int. 2017, 2017. [CrossRef]

54. Marín-García, P.J.; López-Luján, M.C.; Ródenas, L.; Martínez-Paredes, E.; Blas, E.; Pascual, J.J. Plasma urea nitrogen as an indicator of amino acid imbalance in rabbit diets. World Rabbit Sci. 2020, 28, 63-72. [CrossRef]

55. Ogbuewu, I.P.; Emenalom, O.O.; Okoli, I.C. Alternative feedstuffs and their effects on blood chemistry and haematology of rabbits and chickens: A review. Comp. Clin. Path. 2017, 26, 277-286. [CrossRef]

56. Martins, A.A.; Araújo, A.R.; Graça, A.; Caetano, N.S.; Mata, T.M. Towards sustainable wine: Comparison of two Portuguese wines. J. Clean. Prod. 2018, 183, 662-676. [CrossRef] 
57. Wood, J.D.; Enser, M.; Fisher, A.V.; Nute, G.R.; Sheard, P.R.; Richardson, R.I.; Hughes, S.I.; Whittington, F.M. Fat deposition, fatty acid composition and meat quality: A review. Meat Sci. 2008, 78, 343-358. [CrossRef] [PubMed]

58. Gutiérrez, A.; Del Río, J.C.; Martínez-Íñigo, M.J.; Martínez, M.J.; Martínez, Á.T. Production of new unsaturated lipids during wood decay by ligninolytic basidiomycetes. Appl. Environ. Microbiol. 2002, 68, 1344-1350. [CrossRef]

59. Bożena, M.; Przemysław, P.; Jan, L.; Katarzyna, S.-Z. Lentinula edodes (Shiitake)—Biological activity. Med. Int. Revuo-Int. Med. Rev. 2017, 3, 188-194.

60. Çaglarırmak, N. The nutrients of exotic mushrooms (Lentinula edodes and Pleurotus species) and an estimated approach to the volatile compounds. Food Chem. 2007, 105, 1188-1194. [CrossRef]

61. Nagy, K.; Tiuca, I.-D. Importance of Fatty Acids in Physiopathology of Human Body. In Fatty Acids; Catala, A., Ed.; IntechOpen: London, UK, 2016; pp. 3-22. 